\title{
Recovery of Amiloride-Sensitive Neural Coding during Regeneration of the Gustatory Nerve: Behavioral-Neural Correlation of Salt Taste Discrimination
}

\author{
Keiko Yasumatsu, ${ }^{1}$ Hideo Katsukawa, ${ }^{2}$ Kazushige Sasamoto, ${ }^{1}$ and Yuzo Ninomiya ${ }^{1}$ \\ ${ }^{1}$ Section of Oral Neuroscience, Graduate School of Dental Sciences, Kyushu University, Fukuoka 812-8582, Japan, and ${ }^{2}$ Department of Oral Physiology, \\ Asahi University School of Dentistry, Gifu 501-0296, Japan
}

\begin{abstract}
The chorda tympani (CT) nerve innervating the anterior tongue contains two types of NaCl-responsive fibers: one, the N-type, receives input from receptor cells, the $\mathrm{NaCl}$ responses of which are strongly inhibited by amiloride, whereas the other, the E-type, receives input from cells poorly sensitive or insensitive to amiloride. To investigate the formation of this differentially responsive neural system, we crushed the mouse CT nerve and examined the subsequent recovery of $\mathrm{NaCl}$ responses and amiloride sensitivity of the regenerated nerve and behavioral discrimination between $\mathrm{NaCl}$ and $\mathrm{KCl}$. At 2 weeks after the nerve crush, no significant response of the nerve to chemical stimuli was observed. At 3 weeks, responses to salts gradually reappeared. In this period, almost all single fibers responding to $\mathrm{NaCl}$ were insensitive to amiloride (E-type). At 4 weeks, some of the single fibers showed amiloride sensitivity (N-type) and behavioral discrimination between $\mathrm{NaCl}$ and $\mathrm{KCl}$ reappeared. After $\geq 5$ weeks, the number of $\mathrm{N}$-type fibers had reached the control level and became approximately equal to that of E-type fibers. During the course of recovery, $\mathrm{N}$-type and E-type fibers were clearly distinguishable on the basis of their amiloride sensitivities, their $\mathrm{KCl} / \mathrm{NaCl}$ response ratios, and their concentration-response relationships to $\mathrm{NaCl}$. These results suggest that two salt-responsive systems are independently reformed after the nerve crush. The selective synapse reformation may account for recovery of behavioral discrimination between $\mathrm{NaCl}$ and $\mathrm{KCl}$ after taste nerve crush and regeneration. It may also explain stable sensory coding for taste quality during the continuous turnover of receptor cells in the healthy animal.
\end{abstract}

Key words: taste nerve; regeneration; sodium taste response; behavioral discrimination; amiloride sensitivity; synapse reformation

\section{Introduction}

It is known that taste cells are replaced with an average life span of $\sim 10 \mathrm{~d}$ in mammals (Beidler and Smallman, 1965; Farbman, 1980; Takeda et al., 1981). This turnover is accompanied by continuing synaptic reconnection between newly formed taste cells and gustatory fibers. Little is known about how a constant afferent message for taste quality coding is maintained and transmitted to the brain under such continual synaptic reconnection. Oakley (1975) addressed this issue by comparing responses of branches of a single taste fiber of the cat chorda tympani (CT) nerve, innervating the anterior tongue, to various taste stimuli. He found that the branches have very similar relative responsiveness to the stimuli. This implies that a given class of taste axons maintains a persistent association with its corresponding class of receptor cells.

Recent studies further addressed this issue by using a selective sodium taste inhibitor, amiloride, a blocker of the epithelial sodium channel $\mathrm{ENaC}$. These studies demonstrated the existence of

Received Dec. 27, 2002; revised Feb. 3, 2003; accepted Feb. $25,2003$.

This work was supported by a grant from the Program for Promotion of Basic Research Activities for Innovative Bioscience from Bio-oriented Technology Research Advancement Institution; Grants-in-Aid 12470394 and 09557147 (to Y.N.) for Scientific Research from the Ministry of Education, Culture, Sports, Science and Technology of Japan; and the Salt Science Foundation of Japan (Grant 9952).We thank Dr. Bernd Lindemann for critical reading of this manuscript and valuable comments.

Correspondence should be addressed to Dr. Yuzo Ninomiya, Section of Oral Neuroscience, Graduate School of Dental Sciences, Kyushu University, 3-1-1 Maidashi, Higashi-ku, Fukuoka 812-8582, Japan. E-mail: nino@dent.kyushu-u.ac.jp.

Copyright $\odot 2003$ Society for Neuroscience $\quad$ 0270-6474/03/234362-07\$15.00/0 two types of rodent CT fibers. One type receives input from receptor cells that narrowly respond to $\mathrm{NaCl}(\mathrm{LiCl})$, the $\mathrm{NaCl}$ response being strongly inhibited by amiloride (labeled N-type). The other type receives input from cells broadly responsive to electrolytes, including various salts and acids, and shows almost no amiloride sensitivity (E-type or H-type) (Ninomiya and Funakoshi, 1988; Hettinger and Frank, 1990). The glossopharyngeal (IXth) nerve, innervating the posterior tongue, has primarily the E-type (Formaker and Hill, 1991; Ninomiya et al., 1991). A subsequent study (Ninomiya, 1998) examined the amiloride sensitivity of regenerated and cross-regenerated mouse CT and IXth nerves and found approximately equal numbers of $\mathrm{N}$-type and E-type fibers in all of the intact, regenerated, and crossregenerated CT nerves. This suggests that regenerated $\mathrm{N}$-type or E-type axons selectively recouple with amiloride-sensitive (AS) or amiloride-insensitive (AI) taste cells, regardless of whether they innervate the front or the back of the tongue. Collectively, previous studies suggest selective synapse formation between taste axons and cells, which may also explain stable responsiveness of taste neurons during continuous receptor cell turnover.

Our previous study (Ninomiya, 1998), however, did not investigate the processes of reformation of the two differential neural systems for salt responses (AI and AS systems) during the CT regeneration. It remains unclear whether incoming regenerated CT axons would (1) induce AI or AS properties after synapse formation with identical progenitors, (2) innervate taste cells randomly followed by elimination of mismatched branches, or (3) selectively innervate AS or AI taste progenitor cells. The pur- 
pose of the present study, therefore, is to test these possibilities. To accomplish this, we crushed the mouse CT nerve and examined the subsequent recovery of $\mathrm{NaCl}$ responses of the regenerated nerve and their amiloride inhibition during the course of the nerve regeneration. Because it was suggested that the AS system of the CT plays a crucial role in the detection of sodium salts (Spector et al., 1996), we also examined concomitant changes in behavioral discrimination between $\mathrm{NaCl}$ and $\mathrm{KCl}$ during the nerve regeneration.

\section{Materials and Methods}

Experimental manipulation. All experimental procedures were approved by the committee for Laboratory Animal Care and Use at Kyushu University (Fukuoka, Japan). Subjects were adult male and female C57BL/ 6NCrj mice (Charles River Japan, Tokyo, Japan), 8-20 weeks of age, ranging in weight from 20 to $32 \mathrm{gm}$. At $8-10$ weeks of age, mice were divided into five groups, including one intact control group and four experimental (nerve-crush) groups with bilateral CT nerve crush. Four nerve-crush groups (2, 3, 4, and $\geq 5$ weeks groups) were used for obtaining data at the time points of $14-16,21-23,28-30$, and $\geq 35 \mathrm{~d}(<50 \mathrm{~d})$ after the CT nerve crush and regeneration, respectively. Each animal in each group was used for either behavioral or electrophysiological experiments. For the CT nerve crush, animals were anesthetized with pentobarbital sodium ( $40-50 \mathrm{mg} / \mathrm{kg}$, i.p.; Nembutal; Abbott Laboratories, Abbott Park, IL), and the bilateral CT nerves were exposed at $\sim 5 \mathrm{~mm}$ rostrally apart from their entry to the bulla and repeatedly crushed at a single point with number 5 forceps until only a thin strand of nerve sheath remained (5-10 crushes). We chose nerve crush instead of nerve section, because in our pilot study we found that time needed for recovery of taste responses after nerve section extensively varies among individuals, and that time needed for recovery of taste responses after nerve crush was much more stable. Intact control animals received no manipulations.

Behavioral experiments: measurements for discrimination between $\mathrm{NaCl}$ and $\mathrm{KCl}$. The conditioned taste aversion paradigm was used for measurements of behavioral discrimination between $\mathrm{NaCl}$ and $\mathrm{KCl}$ before and after the CT nerve crush and regeneration. We defined behavioral discrimination between $\mathrm{NaCl}$ and $\mathrm{KCl}$ in mice as a case in which mice showed lick rates for $\mathrm{KCl}$ that were statistically different from those for $\mathrm{NaCl}$ during a generalization task after avoidance conditioning to $\mathrm{NaCl}$. Thus, our test is different from a discrimination task previously performed by Spector et al. (1996). The conditioned stimulus for all groups was $0.3 \mathrm{M} \mathrm{NaCl}$. Test stimuli (TSs) used were $0.01,0.03,0.1,0.3$, and $1.0 \mathrm{M}$ $\mathrm{NaCl}$ (Nacalai Tesque Inc., Kyoto, Japan) with and without $30 \mu \mathrm{M}$ amiloride (Sigma, St. Louis, MO) and 0.01, 0.03, 0.1, 0.3, and 1.0 $\mathrm{M} \mathrm{KCl} \mathrm{(Wako}$ Ltd., Osaka, Japan) with and without $30 \mu \mathrm{M}$ amiloride. These chemicals were dissolved in distilled water. Experimental details for this test have been described previously (Ninomiya et al., 1984b). Briefly, on the first day of training, each animal was placed in a test cage and given ad libitum access to distilled water from a drinking tube during a $1 \mathrm{hr}$ session. From the second through fifth days, training session time was reduced from 1 $\mathrm{hr}$ to $30 \mathrm{~min}$. During this period, the animal was trained to drink distilled water on an interval schedule, consisting of a $10 \mathrm{sec}$ period of presentation of distilled water alternated with $20 \mathrm{sec}$ intertrial intervals, resulting in $30-50$ trials during the $30 \mathrm{~min}$ session. On the sixth day, each animal was given access to $0.3 \mathrm{M} \mathrm{NaCl}$ solution during the interval schedule for $>20$ times and then given an intraperitoneal injection of $\mathrm{LiCl}(230 \mathrm{mg} /$ $\mathrm{kg}$; unconditioned stimulus), to induce gastrointestinal malaise. The conditioning against $\mathrm{NaCl}$ occurred on $14,21,28$, or $\geq 35 \mathrm{~d}$ after nerve crush for the four experimental groups. From the seventh to ninth days, the number of licks for test solutions by each animal was counted during first $10 \mathrm{sec}$ after the first lick. On each test day, the first test stimulus given to the animal was always distilled water, followed by a $0.3 \mathrm{M} \mathrm{NaCl}$ solution in the second trial. Animals that avoided the $\mathrm{NaCl}$ solution were repeatedly presented with distilled water and each of the TSs without amiloride in a randomized order. Then TSs with amiloride were tested. Testing continued until the mice no longer licked the distilled water within $7 \mathrm{sec}$ after the animal's first lick on a certain trial. The response of each animal to each stimulus was measured by the mean number of licks during the repeated $10 \mathrm{sec}$ presentations.

Electrophysiological experiments: recordings of responses from intact and regenerated CT. At $\sim 2-5$ weeks or more after the $\mathrm{CT}$ crush, nerve-crush groups were reoperated under pentobarbital anesthesia to expose the regenerated nerve and to dissect a single fiber or a few fibers of the nerve for electrophysiological recording. The procedures of dissection and recording of responses of the regenerated nerve and fibers were the same as those used previously for the nonoperated normal CT nerve and fibers of intact animals (Ninomiya et al., 1984a, 1991; Ninomiya, 1997). Briefly, under pentobarbital anesthesia, the trachea of each animal was cannulated, and the mouse was then fixed in the supine position with a head holder to allow dissection of the CT nerve. The hypoglossal nerve was transected bilaterally to prevent tongue movements. The right CT nerve was exposed at its exit from the lingual nerve by removal of medial pterygoid muscle. The CT nerve was then dissected free from surrounding tissues and cut at the point of its entry to the bulla. For whole-nerve recording, the entire nerve was placed on a silver wire electrode. For single-fiber recording, a single fiber or a few fibers of the nerve were teased apart with a pair of needles and lifted on the electrode. An indifferent electrode was placed in nearby tissue. Neural responses resulting from chemical stimulations of the tongue were fed into an amplifier (K-1; Iyodenshikogaku, Nagoya, Japan), monitored on an oscilloscope and audiomonitor, recorded on a recorder (WS-641G; Nihon-kohden, Tokyo, Japan), and stored on magnetic tape for later analysis. Whole-nerve responses were integrated by an integrator having a time constant of $1.0 \mathrm{sec}$.

Chemical, electrical, and cold stimulations to the tongue. The anterior half of the tongue was enclosed in a flow chamber made of silicone rubber (Ninomiya and Funakoshi, 1981a). Solutions were delivered into the chamber by gravity flow and flowed over the tongue for a controlled period. Solutions used as chemical stimuli were: $0.01,0.03,0.1,0.3$, and $1.0 \mathrm{M} \mathrm{NaCl}$ with and without $30 \mu \mathrm{M}$ amiloride; $0.3 \mathrm{M} \mathrm{NaCl}$ with 10 or 100 $\mu \mathrm{M}$ amiloride; $0.01,0.03,0.1,0.3$, and $1.0 \mathrm{M} \mathrm{KCl}$ with and without $30 \mu \mathrm{M}$ amiloride; and $0.1 \mathrm{M} \mathrm{NH}_{4} \mathrm{Cl}$ (Nacalai Tesque Inc., Kyoto, Japan). These chemicals were dissolved in distilled water and used at $\sim 24^{\circ} \mathrm{C}$. For whole-nerve recording in the second week, responses of the CT to cold distilled water at $\sim 10^{\circ} \mathrm{C}$ and electrical stimulation (ES) applied to the tongue were tested, because this group responded to chemical stimuli only slightly or not at all. For ES, an Ag-AgCl electrode was placed on the inside wall of the flow chamber or was placed directly on the tongue when required. The $\mathrm{Ag}-\mathrm{AgCl}$ indifferent electrode was positioned in nearby tissue. Anodal current was passed through the tongue from a ramp current generator (Densi-sekkei, Nagoya, Japan). The bathing medium used during the current stimulation was $0.001 \mathrm{M} \mathrm{NaCl}$ (Ninomiya and Funakoshi, 1981b). We found that anodal current with the intensity of $20 \mu \mathrm{A}$ (the rate of rise at $100 \mu \mathrm{A} / \mathrm{sec}$ and the duration of $\sim 20 \mathrm{sec}$ ) provoked robust responses in the $\mathrm{CT}$ at the 2 weeks nerve crush. Thus, we decided to use the response to the anodal current as the standard to calculate relative magnitudes of response to each chemical stimulus at each experimental period after nerve crush. For single-fiber recording, responses to tactile stimulation of the tongue for each unit were examined by lightly pressing the tongue surface with a glass rod (tip diameter, $\sim 2 \mathrm{~mm}$ ). The order of chemical stimulations for whole-nerve and single-fiber recordings was $0.1 \mathrm{M} \mathrm{NH}_{4} \mathrm{Cl}, 0.01-1.0 \mathrm{M} \mathrm{NaCl}, 0.01-1.0 \mathrm{M} \mathrm{KCl}$, and $0.01-1.0 \mathrm{M}$ $\mathrm{NaCl}$ with $30 \mu \mathrm{M}$ amiloride; $0.01-1.0 \mathrm{M} \mathrm{KCl}$ with $30 \mu \mathrm{M}$ amiloride; and $0.3 \mathrm{M} \mathrm{NaCl}$ with 10 or $100 \mu \mathrm{M}$ amiloride. After the series of stimulations with amiloride, $0.01-1.0 \mathrm{M} \mathrm{NaCl}$ without amiloride was repeatedly applied to check the recovery after amiloride inhibition. In most cases of whole-nerve recording, but also in some single-fiber recordings, after confirming the recovery ( $>85 \%$ of control levels of responses)m these series of stimulations were repeated. During chemical stimulation of the tongue, the test solution flowed for $\sim 25 \mathrm{sec}$ at the same flow rate as the distilled water used for rinsing the tongue $(\sim 0.5 \mathrm{ml} / \mathrm{sec})$. The tongue was rinsed during the interval of $\sim 1$ min between successive stimulations. The stability of each preparation for whole-nerve recording was monitored by the periodic application of $\mathrm{ES}$ or $0.1 \mathrm{M} \mathrm{NH}_{4} \mathrm{Cl}$. A recording was considered to be stable when the $\mathrm{ES}$ or $\mathrm{NH}_{4} \mathrm{Cl}$ response magnitudes at the beginning and end of each stimulation series deviated by no more than 
$15 \%$. Only responses from stable recordings were used in the data analysis.

Data analysis of neural activities. In the analysis of whole-nerve responses, the magnitude of the integrated responses at 5, 10, 15, and $20 \mathrm{sec}$ after stimulus onset was measured and averaged. Relative response magnitude (averaged) for each test stimulus was calculated when the response magnitude to ES (20 $\mu \mathrm{A}$ anodal current) was taken as a unity (1.0), and this value was used for statistical analysis. In the analysis of single-fiber responses, single fibers were identified by their uniform spike height, singular wave form, and intervals between contiguous spikes (Ninomiya, 1998; Kawai et al., 2000). Frequency-time histograms of impulse discharges before, during, and after chemical stimulation of the tongue were calculated by means of a spike-analysis system (SAS-1; Iyodenshikogaku). For data analysis, we used the net average frequency for the first $10 \mathrm{sec}$ after the stimulus onset was obtained by subtracting the spontaneous frequency for the $10 \mathrm{sec}$ period before stimulation. We calculated the percentage of amiloride inhibition of responses to $0.3 \mathrm{M} \mathrm{NaCl}$ for each fiber and used the $60 \%$ control response level to classify the fibers as N-type $(<60 \%)$ and E-type $(\geq 60 \%)$. Previous studies have shown that the $60 \%$ level was the most appropriate level to differentiate the two groups of fibers with different amiloride sensitivities in rodents (Ninomiya and Funakoshi, 1988; Hettinger and Frank, 1990; Ninomiya, 1998).

\section{Results}

Behavioral discrimination between $\mathrm{NaCl}$ and $\mathrm{KCl}$ after nerve crush and regeneration

In the control group, lick rates to concentration series (0.01-1.0 $\mathrm{M})$ of $\mathrm{NaCl}$ were significantly different from those of $\mathrm{KCl}$ (repeated ANOVA; $\left.F_{(1,40)}=95.8 ; p<0.001\right)$, although mice similarly avoided both $1.0 \mathrm{M}$ salts with very low lick rates $(<10$ licks per 10 sec) (Fig. 1, control). Mice clearly showed a difference in licks for $\mathrm{NaCl}$ with and without amiloride $\left(F_{(1,40)}=79.4 ; p<0.001\right)$ but no significant difference in lick rates for $\mathrm{NaCl}$ with amiloride and $\mathrm{KCl}\left(F_{(1,40)}=0.1 ; p>0.05\right)$. Thus, control mice could behaviorally discriminate between $\mathrm{NaCl}$ and $\mathrm{KCl}$ in a wide range of concentrations $(0.01-0.3 \mathrm{M})$, yet this discrimination was abolished by amiloride. The behavioral discrimination between $\mathrm{NaCl}$ and $\mathrm{KCl}$ was still absent 2 weeks after crush of the CT $\left(F_{(1,40)}=2.5\right.$; $p>0.05$ ) (Fig. 1, 2 weeks). Salt discrimination started to recover 4 weeks after nerve crush. At this time, lick rates for $\mathrm{NaCl}$ and $\mathrm{KCl}$ $(0.1$ and $0.3 \mathrm{M})$ were significantly different (Student's $t$ test; $p<$ 0.05-0.001) (Fig. 1, 4 weeks). Also, lick rates for 0.1 and $0.3 \mathrm{M}$ $\mathrm{NaCl}$ with and without amiloride were different at this time $(t$ test; $p<0.05)$, suggesting beginning restoration of amiloride sensitivity. At $\geq 5$ weeks, lick rates to concentration series of $\mathrm{NaCl}$ or $\mathrm{KCl}$ with and without amiloride became similar to those of the control and showed significant differences between $\mathrm{NaCl}$ and $\operatorname{KCl}\left(F_{(1,40)}=73.0 ; p<0.001\right)$ and between $\mathrm{NaCl}$ with and without amiloride $\left(F_{(1,40)}=53.9 ; p<0.001\right)$. This suggested a complete recovery of discrimination between $\mathrm{NaCl}$ and $\mathrm{KCl}$ and of amiloride sensitivity.

\section{Whole-nerve responses of the regenerated CT to salts}

At 2 weeks after crushing of the CT, no significant neural responses to salt stimuli were observed. However, anodal current and cold stimulation applied to the tongue produced robust responses in the nerve at this stage (Fig. 2). At 3 weeks, responses to salts reappeared, although $\mathrm{NaCl}$ responses were not yet inhibited by amiloride ( $t$ test; $p>0.05$ ) (see Figs. $2-4$ ). At this stage, the order of magnitude of salt responses was $\mathrm{NH}_{4} \mathrm{Cl}>\mathrm{KCl}=\mathrm{NaCl}$ (Figs. 2, 3). At 4 weeks, responses to $\mathrm{NaCl}$ increased relative to $\mathrm{KCl}$, and responses to 0.1 and $0.3 \mathrm{M} \mathrm{NaCl}$ were significantly inhibited by amiloride ( $t$ test; $p<0.05$ ) (Figs. 2, 3). At this stage,

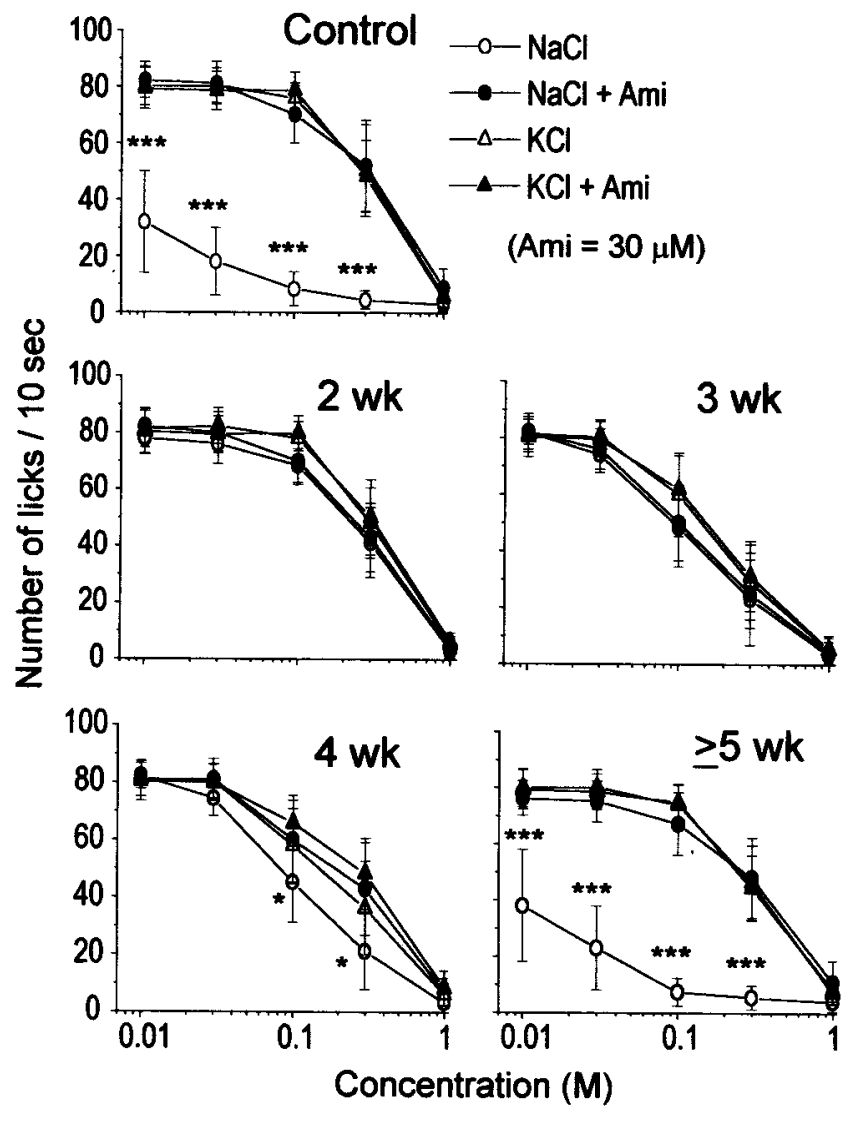

Figure 1. Lick rates (number of licks per $10 \mathrm{sec}$ ) to concentration series of $\mathrm{NaCl}$ and $\mathrm{KCl}$ with and without $30 \mu \mathrm{m}$ amiloride (Ami) in the intact control group ( $n=6$ each) and experimental groups ( $n=6$ ) at 2, 3, 4, and $\geq 5$ weeks after bilateral CT nerve crush. Values indicated are means \pm SD. The mean lick rate for the conditioned stimulus $(0.3 \mathrm{~m} \mathrm{NaCl})$ in each group was $7 \pm 3$ (control), $39.7 \pm 11.5$ ( 2 weeks), $27.8 \pm 16.2$ (3 weeks), $21.7 \pm 13.8$ (4 weeks), or $7 \pm$ 4 ( $\geq 5$ weeks), respectively. Lick rates for $\mathrm{NaCl}$ were significantly different from those either for $\mathrm{KCl}$ or for $\mathrm{NaCl}$ with amiloride in intact control and experimental mice at 4 weeks $(0.1$ and $0.3 \mathrm{~m})$ and $\geq 5$ weeks after nerve crush $(0.01-0.3 \mathrm{~m})$ : Student's $t$ test; ${ }^{*} p<0.05 ;{ }^{* * *} p<0.001$. wk, Weeks.

amiloride was effective already at concentration of $10 \mu \mathrm{M}$, and it significantly inhibited $0.3 \mathrm{M} \mathrm{NaCl}$ responses, as in the control group (Fig. 4). At $\geq 5$ weeks, responses to concentration series of $\mathrm{NaCl}$ or $\mathrm{KCl}$ with and without amiloride became similar to those in intact control mice with significant differences between responses to $\mathrm{NaCl}$ with and without amiloride $\left(F_{(1,32)}=76.2, p<\right.$ 0.001 for the $\geq 5$ weeks group; $F_{(1,32)}=45.6, p<0.001$ for the control group). Thus, the whole-nerve recordings showed differences in $\mathrm{NaCl}$ and $\mathrm{KCl}$ responses and amiloride inhibition of $\mathrm{NaCl}$ responses, as did the behavioral data. There was only a slight difference in responses to $0.03 \mathrm{M} \mathrm{NaCl}$ at $\geq 5$ weeks; unlike in the control group, these responses were not significantly inhibited by amiloride ( $t$ test; $p>0.05$ ) (Figs. $2-4$ ).

\section{Single-fiber responses of the regenerated CT to salts}

Consistent with results from whole-nerve recording, almost no single CT fiber responded to chemical stimuli at 2 weeks after nerve crush. Instead, 16 of 17 fibers responded only to tactile stimulation of the tongue. One fiber showing very weak responses to 0.3 and $1.0 \mathrm{M} \mathrm{NaCl}$ exhibited no clear amiloride inhibition (E-type; Table 1). At 3 weeks, some fibers showed robust responses to 0.3 and $1.0 \mathrm{M} \mathrm{NaCl}$, but most fibers responding to $\mathrm{NaCl}$ were of the E-type (see Fig. 6, Table 1). At this stage, two 

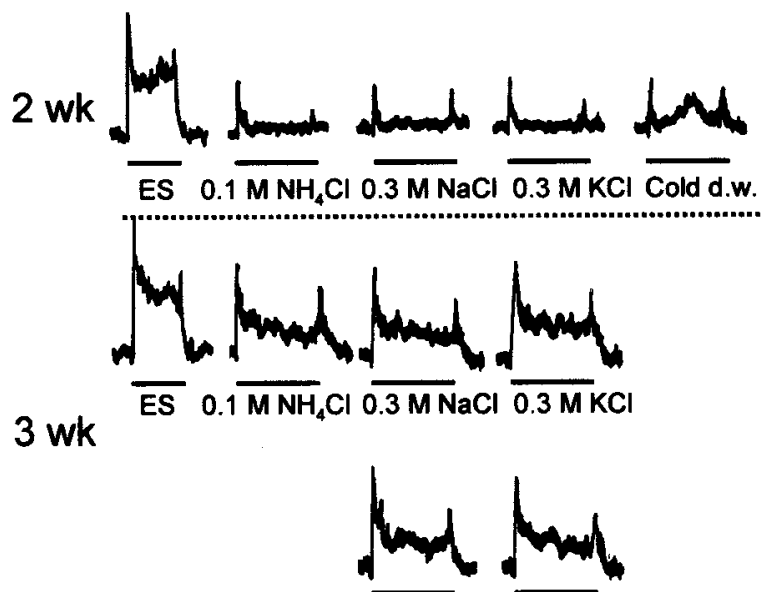

$0.3 \mathrm{M} \mathrm{NaCl}+\mathrm{Ami} \quad 0.3 \mathrm{M} \mathrm{KCl}+A m i$

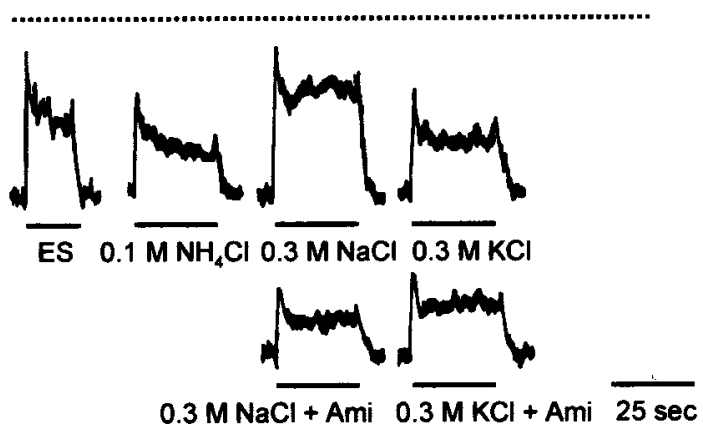

Figure 2. Sample recordings of integrated whole-nerve responses of the regenerated $\mathrm{CT}$ to anodal current with $20 \mu \mathrm{A}(\mathrm{ES}), 0.1 \mathrm{M} \mathrm{NH}_{4} \mathrm{Cl}, 0.3 \mathrm{~m} \mathrm{NaCl}$ with and without $30 \mu \mathrm{m}$ amiloride (Ami), $0.3 \mathrm{~m} \mathrm{KCl}$ with and without $30 \mu \mathrm{m}$ amiloride, and cold stimulation with distilled water (d.w.) applied to the tongue in experimental mice at 2, 3, and 4 weeks after nerve crush. These examples were taken from recordings using different electronic amplification factors. wk, Weeks.

fibers were classified as N-type (Table 1), showing poor but significant responses to $\mathrm{NaCl}$. At 4 weeks, the number of $\mathrm{N}$-type fibers increased, reaching $\sim 25 \%$ of all regenerated CT fibers (see Fig. 6, Table 1). These $\mathrm{N}$-type fibers, as well as the E-type fiber, briskly responded to $\mathrm{NaCl}$ (see Figs. 5, 8). At $\geq 5$ weeks after nerve crush, there was an approximately equal number of $\mathrm{N}$-type and E-type fibers responding with high-impulse frequencies to $\mathrm{NaCl}$, as in control mice (see Figs. 6, 8, Table 1). From 3 to $\geq 5$ weeks after nerve crush, the distribution of E-type fibers in a plot of percentages of control responses to $\mathrm{NaCl}$ plus amiloride had a peak $(\sim 90 \%)$ at each stage (i.e., it was basically unchanged) (Fig. 6, E-type). In contrast, the $\mathrm{N}$-type population sharply grew during this period and formed a new peak $(\sim 20 \%)$. A bimodal distribution resulted (Fig. 6). Thus, no intermediate group and no clear sensitivity shift of the E-type population appeared during the course of regeneration. Mean response ratios $(\mathrm{KCl} / \mathrm{NaCl})$ of E-type were near 1.0 at all times, similar to the response ratios of controls ( $t$ test; $p>0.05)$. They were clearly different from the response ratios of N-type at 4 weeks and $\geq 5$ weeks and of the corresponding controls $(\sim 0.25$; $t$ test, $p<0.001)$ (Fig. 7). This suggests that selectivity for $\mathrm{NaCl}$ is much higher in $\mathrm{N}$-type than in E-type at all times after nerve crush. As shown in Figure 8, mean impulse frequencies in response to concentration series of $\mathrm{NaCl}$ in each type gradually increased during the regeneration. The dissociation constant $\left(K_{\mathrm{d}}\right)$ and the maximum response $\left(V_{\max }\right)$ were calculated on the basis of the concentration-response relationship for $\mathrm{NaCl}$ in each group from 3 to $\geq 5$ weeks after the

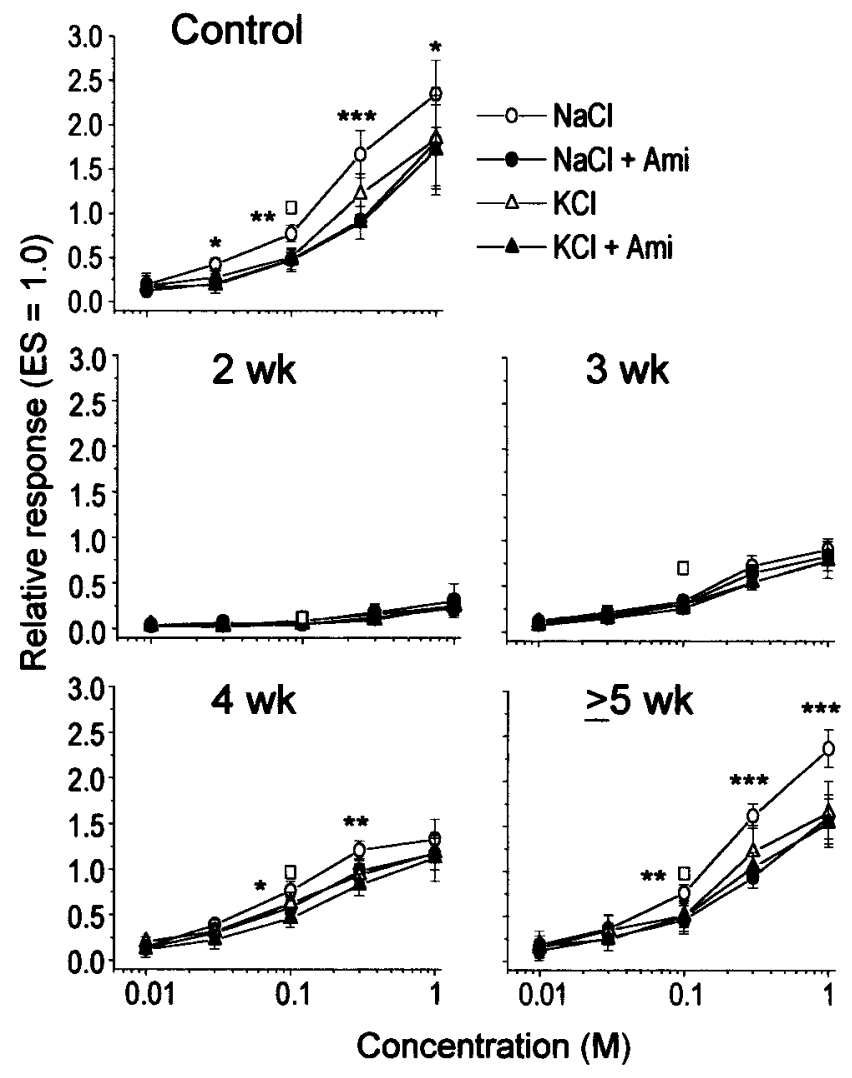

Figure 3. Relative responses to concentration series of $\mathrm{NaCl}$ and $\mathrm{KCl}$ with and without $30 \mu \mathrm{m}$ amiloride in the intact control group $(n=5)$ and experimental groups ( $n=5$ each) at 2, 3, 4, and $\geq 5$ weeks after nerve crush. Response to anodal current with $20 \mu \mathrm{A}$ applied to the tongue was used as a unity (1.0). Responses to $0.1 \mathrm{M} \mathrm{NH}_{4} \mathrm{Cl}$, as an alternative control, are indicated by open squares. Values indicated are means $\pm \mathrm{SD}$. Responses to $\mathrm{NaCl}$ were statistically significantly different from those to $\mathrm{NaCl}$ with amiloride $(\mathrm{NaCl}+\mathrm{Ami})$ in intact control group $(0.03-$ $1.0 \mathrm{M})$ and experimental groups at 4 weeks $(0.1$ and $0.3 \mathrm{M})$ and $\geq 5$ weeks after nerve crush $(0.1-1.0 \mathrm{M}) . t$ test; ${ }^{*} p<0.05 ;{ }^{* *} p<0.01 ;{ }^{* * *} p<0.001$. wk, Weeks.

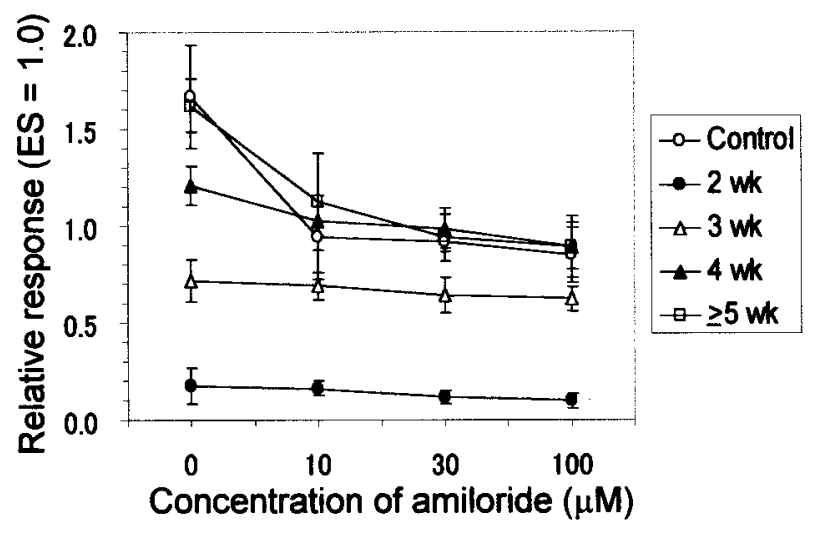

Figure 4. Relative responses to $0.3 \mathrm{M} \mathrm{NaCl}$ with 10,30 , and $100 \mu \mathrm{m}$ amiloride and without amiloride ( 0$)$ in intact control $(n=5)$ and experimental groups $(n=5$ each). Response to anodal current with $20 \mu \mathrm{A}$ applied to the tongue was used as a unity (1.0). Values indicated are means $\pm S D$. Responses to $0.3 \mathrm{~m} \mathrm{NaCl}$ were significantly inhibited by $\geq 10 \mu \mathrm{m}$ amiloride in intact control $(t$ test; $p<0.001)$ and experimental groups at 4 weeks $(p<0.05)$ and $\geq 5$ weeks $(p<0.001)$ after nerve crush. wk, Weeks.

nerve crush (Table 2). Both in E-type and in N-type, the $V_{\max }$ values gradually recovered, nearly reaching the control levels during this period. In contrast, the $K_{\mathrm{d}}$ value of the E-type sharply decreased, from $98.9 \mathrm{~mm}$ (237.2\% of controls) at 3 weeks to 32.5 
Table 1. Numbers of tactile, E-type, and N-type fibers in control and experimental groups

\begin{tabular}{lcccc}
\hline Group & Tactile & E-type & N-type & Total \\
\hline Control & $1(3.1 \%)$ & $15(46.9 \%)$ & $16(50.0 \%)$ & 32 \\
2 weeks & $16(94.1 \%)$ & $1(5.9 \%)$ & $0(0 \%)$ & 17 \\
3 weeks & $4(16.7 \%)$ & $18(75.0 \%)$ & $2(8.3 \%)$ & 24 \\
4 weeks & $3(12.5 \%)$ & $15(62.5 \%)$ & $6(25.0 \%)$ & 24 \\
$\geq 5$ weeks & $2(6.5 \%)$ & $14(45.2 \%)$ & $15(48.4 \%)$ & 31 \\
\hline
\end{tabular}

Each figure in parentheses indicates percentage of total fibers in each class.

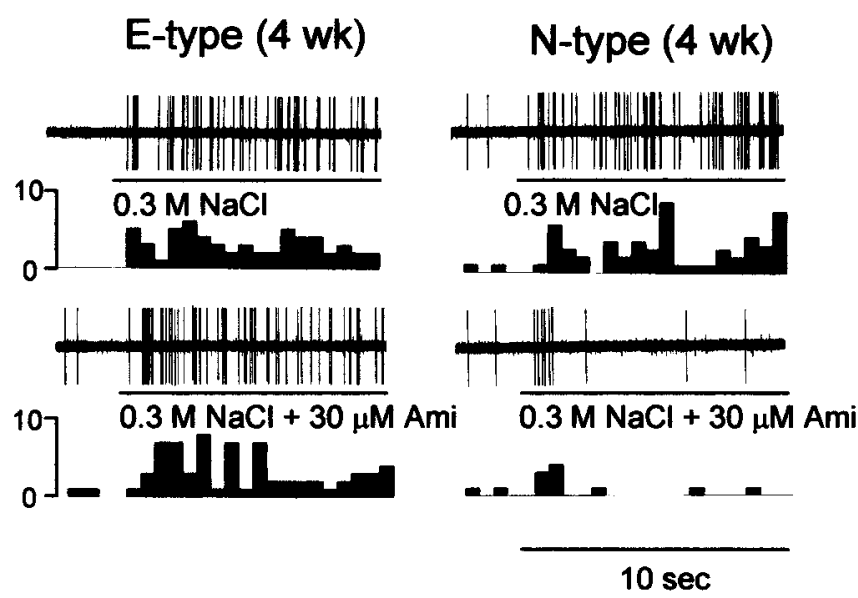

Figure 5. Sample recordings and impulse frequency histograms for responses of E-type and $\mathrm{N}$-type fibers to $0.3 \mathrm{~m} \mathrm{NaCl}$ with and without $30 \mu \mathrm{m}$ amiloride (Ami). wk, Weeks.

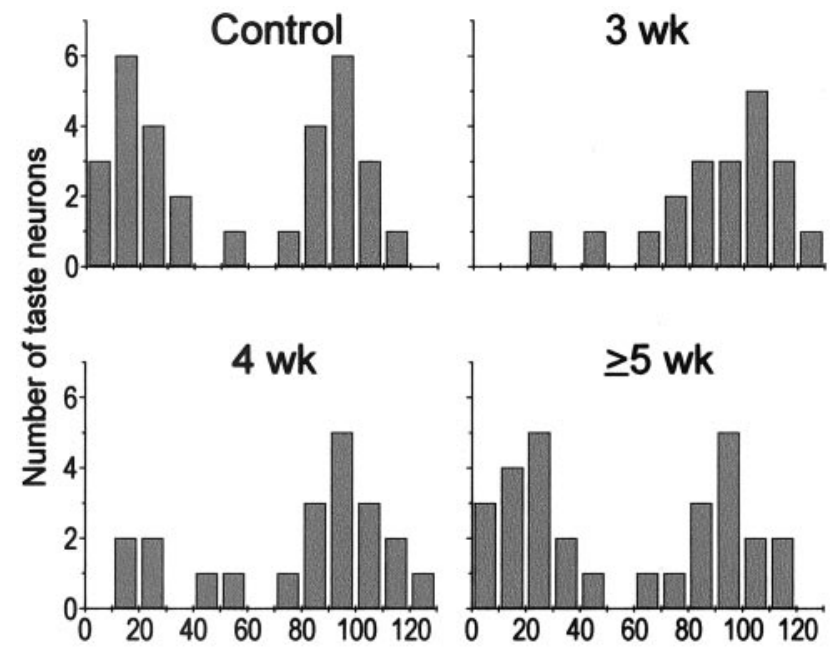

Percent control response to $\mathrm{NaCl}$ with $\mathrm{Ami}$ (without $\mathrm{Ami}=100$ )

Figure 6. Distributions of taste fibers along with their percentage control responses to $0.3 \mathrm{M}$ $\mathrm{NaCl}$ with $30 \mu \mathrm{m}$ amiloride (Ami) (control responses to $\mathrm{NaCl}$ without amiloride $=100 \%$ ) in the intact control $(n=31)$ and experimental groups at 3 weeks $(n=20), 4$ weeks $(n=21)$, and $\geq 5$ weeks $(n=29)$ after bilateral CT nerve crush. There were two groups of taste fibers in the distribution (bimodal in shape, amiloride-sensitive and amiloride-insensitive types) for intact control and experimental groups at 4 weeks and 5 weeks after nerve crush, whereas most regenerated fibers of mice at 3 weeks after nerve crush were amiloride insensitive, thereby producing a unimodal distribution. wk, Weeks.

$\mathrm{mm}(77.9 \%$ of controls) at 4 weeks, which is near the control level (41.7 mM). The $K_{\mathrm{d}}$ value of $\mathrm{N}$-type responses, first measurable at 4 weeks, already was $106.3 \mathrm{~mm}$ (133.2\% of controls) [i.e., it was closer to the control level $(79.8 \mathrm{~mm})$ from the beginning].

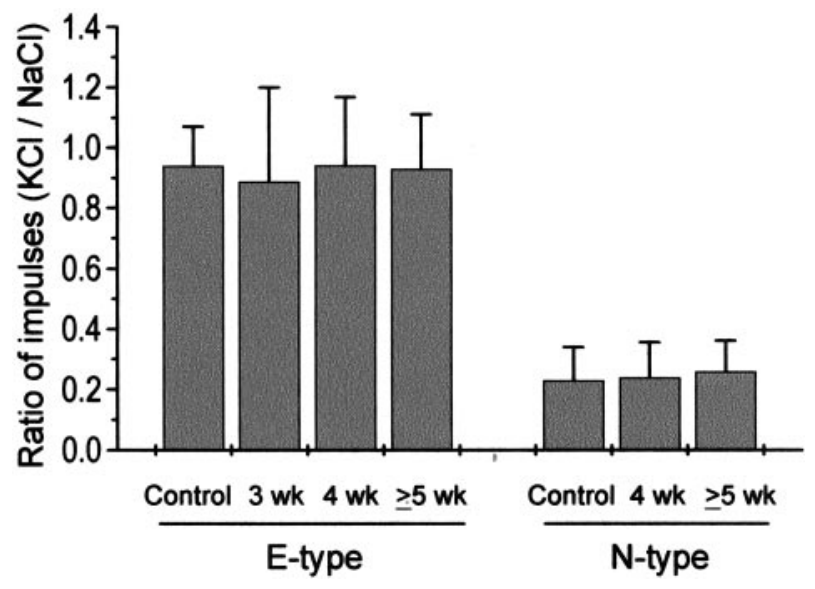

Figure 7. Ratio of impulses to $\mathrm{KCl}$ to those to $\mathrm{NaCl}$ in E-type and $\mathrm{N}$-type fibers in intact control ( $n=14$ each of E-type and N-type) and experimental groups at 3 weeks ( $n=12$, E-type only), 4 weeks ( $n=12$ for E-type and 6 for N-type), and $\geq 5$ weeks ( $n=14$ each) after bilateral CT nerve crush. wk, Weeks.

\section{E-type}

\section{N-type}

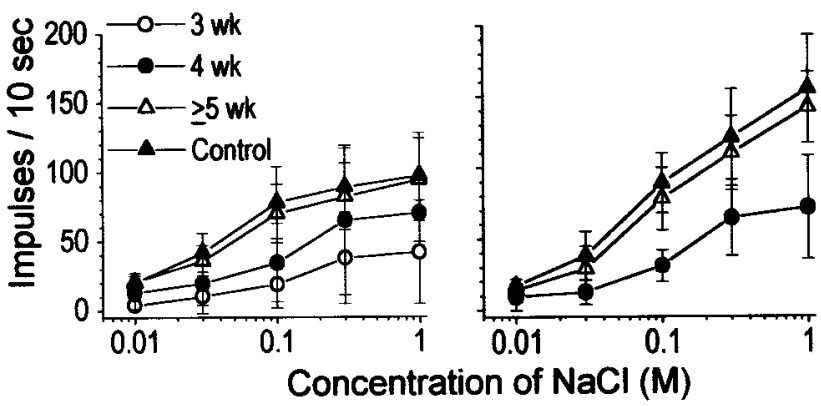

Figure 8. Impulses (per $10 \mathrm{sec}$ ) to concentration series of $\mathrm{NaCl}$ in E-type and $\mathrm{N}$-type fibers in intact control $(n=8)$ and experimental groups $(n=5-8)$ at $2,3,4$, and $\geq 5$ weeks after bilateral CT nerve crush. Values indicated are means \pm SD. wk, Weeks.

Table 2. $K_{\mathrm{d}}$ and $V_{\max }$ of E-type and $\mathrm{N}$-type fibers obtained from the kinetic analysis of the concentration-response relationship for $\mathrm{NaCl}$ in control and experimental groups

\begin{tabular}{|c|c|c|}
\hline & E-type (\% of control) & N-type (\% of control) \\
\hline \multicolumn{3}{|l|}{ Control } \\
\hline$K_{\mathrm{d}}$ & $41.7 \mathrm{~mm}(100)$ & $79.8 \mathrm{~mm}(100)$ \\
\hline$V_{\max }$ & $103.2 \quad(100)$ & $151.1 \quad(100)$ \\
\hline \multicolumn{3}{|l|}{3 weeks } \\
\hline$K_{\mathrm{d}}$ & $98.9 \mathrm{~mm}(237.2)$ & \\
\hline$V_{\max }$ & $43.6 \quad(42.2)$ & \\
\hline \multicolumn{3}{|l|}{4 weeks } \\
\hline$K_{\mathrm{d}}$ & $32.5 \mathrm{~mm}(77.9)$ & $106.3 \mathrm{~mm}(133.2)$ \\
\hline $\begin{aligned} & V_{\max } \\
\geq & 5 \text { weel }\end{aligned}$ & $52.7 \quad(51.1)$ & $45.1 \quad(30.0)$ \\
\hline$K_{\mathrm{d}}$ & $32.5 \mathrm{~mm}(77.9)$ & $84.5 \mathrm{~mm}(105.9)$ \\
\hline$V_{\max }^{a}$ & $87.0 \quad(84.3)$ & $129.6 \quad(85.8)$ \\
\hline
\end{tabular}

Concentration-response relationship for $0.01-1.0 \mathrm{M} \mathrm{NaCl}$ (impulses per $10 \mathrm{sec}$ ) was obtained based on the data of the control ( $n=8$ each for E-type and N-type) and experimental groups at 3 weeks ( $n=5$ each), 4 weeks ( $n=5$ each), and $\geq 5$ weeks ( $n=8$ each) after nerve crush.

\section{Discussion}

The present study examined processes of reformation of the two differential neural systems for salt response, the AI and AS systems, during CT nerve regeneration. Thus, we attempted to test the following three possibilities: that incoming regenerated CT 
axons would (1) induce AI or AS properties after synapse formation with identical progenitors, (2) innervate AS and AI progenitor cells randomly followed by elimination of mismatched branches, or (3) selectively innervate AS or AI progenitor cells. To accomplish this, we crushed the mouse CT nerve and examined subsequent recovery of $\mathrm{NaCl}$ responses of the regenerated nerve and their amiloride inhibition during the course of nerve regeneration. The results revealed that $\mathrm{NaCl}$ responses of the CT started to recover from $\sim 3$ weeks after the nerve crush, whereas amiloride inhibition of $\mathrm{NaCl}$ responses clearly reappeared from $\sim 4$ weeks onward (Figs. 2-8). Thus, reformation of the AI system (E-type axons, AI receptor cells) started $\sim 1$ week earlier than reformation of the AS system (N-type axons, AS cells). Full recovery of both NaCl-responsive systems took at least 5 weeks (Figs. 3, 4, 6, 8). Importantly, segregation of the two types of fibers at each stage was evident from their sensitivities to amiloride and their selectivities ( $\mathrm{KCl} / \mathrm{NaCl}$ response ratios). The number of fibers responding to $\mathrm{NaCl}$ after amiloride formed a bimodal distribution (Fig. 6). No cluster of fibers with intermediate sensitivity to amiloride and no clear sensitivity shift in the E-type population appeared during the course of regeneration. Moreover, response properties of $\mathrm{N}$-type fibers to concentration series of $\mathrm{NaCl}$, judged by $K_{\mathrm{d}}$ values, were also clearly different from those of E-type, right from the beginning of their appearance at 4 weeks after crush (Table 2).

These results may weaken the possibility of the first working hypothesis. The first model may provide one reason for the finding that those mouse $\mathrm{N}$-type CT axons, which cross-reinnervated into the poorly amiloride-sensitive posterior tongue, even form synaptic connections with AS cells (Ninomiya, 1998). This model may allow regenerated axons to contact any cell without specific guidance. For example, N-type axons facing AI might contact them and possibly alter them into their preferential AS type. Thus, these cells will suffer a sensitivity shift, causing the transient appearance of fibers showing intermediate response properties. Yet, no such group and stage were evident during the regeneration. Likewise, the second working hypothesis might also require an intermediate type of fibers, because of the initial random innervation to AI and AS receptor cells. This model may fit well with the finding that the size of the chemical receptive field of sheep $\mathrm{N}$-type fibers diminished as the $\mathrm{NaCl} / \mathrm{NH}_{4} \mathrm{Cl}$ response ratio increased (Nagai et al., 1988). Given that the discharge of an axon would decrease with the number of receptor cells connected to the axon, this model may also require a decrease in impulse frequencies during the particular stage at which elimination of mismatched branches occurs. Yet, impulse discharges of both E-type and N-type fibers kept increasing during the course of regeneration (Fig. 8). Although the possibilities of the former two hypotheses could not be ruled out, because of a possible quick sensitivity shift taking only a few days (Cheal et al., 1977), which may have gone undetected in the present study, the third working hypothesis may be the most likely one. That is, the aforementioned contradictory findings against other models, such as no appearance of an intermediate type of fiber and dichotomized responsiveness either to amiloride or to $\mathrm{NaCl}(\mathrm{KCl} / \mathrm{NaCl}$ response ratio and $K_{\mathrm{d}}$ value) for each axon during the course of regeneration, may be preferentially explained by the model for which regenerated E-type and N-type may independently form synapses with different classes of progenitors. Because it functionally matured, each regenerated axon would extend branches to its corresponding class of receptor cells and thus expand the capacity to respond to $\mathrm{NaCl}$ with higher impulse frequencies (Fig. 8 ) and $V_{\max }$ value (Table 2).
The response of AS receptor cells is thought to require ENaCs on their apical membrane, allowing direct entry of sodium ions into receptor cells and, thus, cell depolarization (Heck et al., 1984; Lindemann, 1996). In contrast, AI cells are sensitive to various electrolytes (salts and acids) and may have more than one response mechanism. One is the transduction system that begins with electroneutral diffusion of the salt across the tight junctions between taste receptor cells and sodium entry into the cells via unspecified basolateral ion channels (Elliott and Simon, 1990; Ye et al., 1991, 1993). The paracellular pathway would not be blocked by mucosal application of amiloride and would allow entry of small ions, such as $\mathrm{Na}^{+}, \mathrm{K}^{+}, \mathrm{H}^{+}$, and $\mathrm{Cl}^{-}$, which may, thus, provoke AI cell responses. In addition, AI responses in E-type may occur through the apical $\mathrm{K}^{+}$channels (Kinnamon et al., 1988), unspecific cation channels (Miyamoto et al., 1998), and hyperpolarization-activated, cyclic nucleotide-gated cation channels (Stevens et al., 2001), which were all suggested to be involved in responses to acids. The constant $K_{\mathrm{d}}$ value in $\mathrm{N}$-type throughout the regeneration and the sharp drop in $K_{\mathrm{d}}$ values in E-type, especially at the initial stages of regeneration in the present study, may in part reflect participation and maturation processes of these single or multiple transduction mechanisms for the AS or AI system, respectively.

Robust responses to anodal currents and cold stimulations observed at 2 weeks after nerve crush imply that the regenerated $\mathrm{CT}$ at this stage might have reached the epithelial tissue just below the tongue surface, although no chemical responsive elements of taste cells were restored as yet. Thus, at this stage, anodal responses may not be chemically mediated (Herness, 1985). It is likely that the anodal current may force small cations to pass through the aforementioned paracellular pathways and activate the nerve fibers directly or via crude AI receptor cells (Ninomiya and Funakoshi, 1981b, 1989). Recovery of the AI system before that of the AS system is compatible with a previous study in gerbils with unilateral CT crush (Cheal et al., 1977). Regenerated gerbil E-type fibers recovered $\sim 14 \mathrm{~d}$ after the crush, whereas $\mathrm{N}$-type fibers recovered a bit later, at $\sim 16 \mathrm{~d}$. Compared with that in gerbils, the recovery rate of overall taste responses in mice is slower. This may be attributable in part to the longer distance to be traversed by the recovering axons (crushed CT just proximal to its union with the lingual nerve in gerbils and at $\sim 5 \mathrm{~mm}$ to its entrance to the bulla in mice) and by a lack of possible influences from the intact side, including centrally mediated efferent control (Hellekant, 1971) and parasympathetic saliva of the submaxillary glands (Catalanotto and Sweeney, 1973) by bilateral nerve crush in the present study. An earlier appearance of the AI system was also found in the course of taste development in rats. The AI system is present at birth, whereas the AS system appears postnatally (Hill and Bour, 1985). Unlike these rodents, hamsters showed constant amiloride inhibition of $\mathrm{NaCl}$ responses from 4 to 8 weeks after CT nerve crush (Cain et al., 1996) and even no clear difference in the developmental appearance of AS and AI systems (Hill, 1988).

The present study in mice confirmed the importance of the AS system for behavioral discrimination between $\mathrm{NaCl}$ and $\mathrm{KCl}$ demonstrated previously in rats (St. John et al., 1995; Spector et al., 1996). Differences in mouse lick rates for $\mathrm{NaCl}$ and $\mathrm{KCl}$ were still absent 2 weeks after the nerve crush and reappeared from 4 weeks (Fig. 3). At this time, electrophysiological data suggested the reappearance of the AS system in the same mice. After $\geq 5$ weeks, like in the control group, mice clearly discriminated between these salts at concentrations from 0.01 to $0.3 \mathrm{M}$. The discrimination was abolished when $\mathrm{NaCl}$ solutions were mixed with 
amiloride (Fig. 1). Later recoveries of salt discrimination after CT damage were reported in rats ( 49 d) (St. John et al., 1995) and in hamsters (16 weeks) (Barry et al., 1993). This may be attributable to the longer distance from the point of nerve injury to taste buds in those studies. Furthermore, regeneration may be more difficult when the CT is damaged at the middle ear, as was found in humans (Saito et al., 2001). Neural inputs from the AS and AI systems are reported to remain largely segregated in the first central gustatory nucleus, the solitary tract, in rodents (Scott and Giza, 1990; Boughter and Smith, 1998; St. John and Smith, 2000). This remained true even after CT nerve crush and during regeneration (Barry, 1999). The segregation may be essential for quality coding of the salt tastes.

In conclusion, the present findings are consistent with the view that regenerating taste axons selectively innervate their corresponding classes of taste progenitor cells. Reformation of synapse connections between matched sets of taste axons and cells (AS and AI systems) restores behavioral salt taste discrimination after CT nerve crush. Selective synapse formation could normally explain the stability of response profiles of particular classes of taste axons, thereby maintaining stable sensory signals for taste quality in the presence of continued receptor cell turnover.

\section{References}

Barry MA (1999) Recovery of functional response in the nucleus of the solitary tract after peripheral gustatory nerve crush and regeneration. J Neurophysiol 82:237-247.

Barry MA, Larson DC, Frank ME (1993) Loss and recovery of sodium-salt taste following bilateral chorda tympani nerve crush. Physiol Behav 53:75-80.

Beidler LM, Smallman RL (1965) Renewal of cells within taste buds. J Cell Biol 27:263-272.

Boughter Jr JD, Smith DV (1998) Amiloride blocks acid responses in NaClbest gustatory neurons of the hamster solitary nucleus. J Neurophysiol 80:1362-1372.

Cain P, Frank ME, Barry MA (1996) Recovery of chorda tympani nerve function following injury. Exp Neurol 141:337-346.

Catalanotto FA, Sweeney EA (1973) Long-term effects of selective desalivation on taste acuity in the rat. Arch Oral Biol 18:941-952.

Cheal M, Dickey WP, Jones LB, Oakley B (1977) Taste fiber responses during reinnervation of fungiform papillae. J Comp Neurol 172:627-646.

Elliott EJ, Simon SA (1990) The anion in salt taste: a possible role for paracellular pathways. Brain Res 535:9-17.

Farbman AI (1980) Renewal of taste cells in rat circumvallate papillae. Cell Tissue Kinet 13:349-357.

Formaker BK, Hill DL (1991) Lack of amiloride sensitivity in SHR and WKY glossopharyngeal taste responses to NaCl. Physiol Behav 50:765-769.

Heck GL, Mierson S, DeSimone JA (1984) Salt transduction occurs through an amiloride sensitive sodium transport pathway. Science 223:403-405.

Hellekant G (1971) Efferent impulses in the chorda tympani nerve of the rat. Acta Physiol Scand 83:203-209.

Herness MS (1985) Neurophysiological and biophysical evidence on the mechanism of electric taste. J Gen Physiol 86:59-87.

Hettinger TP, Frank ME (1990) Specificity of amiloride inhibition of hamster taste responses. Brain Res 513:24-34.

Hill DL (1988) Development of chorda tympani nerve taste responses in the hamster. J Comp Neurol 268:346-356.

Hill DL, Bour TC (1985) Addition of functional amiloride-sensitive components to the receptor membrane: a possible mechanism for altered taste responses during development. Brain Res 352:310-313.

Kawai K, Sugimoto K, Nakashima K, Miura H, Ninomiya Y (2000) Leptin as a modulator of sweet taste sensitivities in mice. Proc Natl Acad Sci USA 97:11044-11049.

Kinnamon SC, Dionne VE, Beam KG (1988) Apical localization of $\mathrm{K}^{+}$ channels in taste cells provided the basis for sour taste transduction. Proc Natl Acad Sci USA 85:7023-7027.

Lindemann B (1996) Taste reception. Physiol Rev 76:719-766.

Miyamoto T, Fujiyama R, Okada Y, Sato T (1998) Sour taste transduction involves activation of NPPB-sensitive conductance in mouse taste cells. J Neurophysiol 80:1852-1859.

Nagai T, Mistretta CM, Bradley RM (1988) Developmental decrease in size of peripheral receptive fields of single chorda tympani nerve fibers and relation to increasing $\mathrm{NaCl}$ taste sensitivity. J Neurosci 8:64-72.

Ninomiya Y (1997) Salt taste responses of mouse chorda tympani neurons: evidences for existence of two different amiloride-sensitive receptor components for $\mathrm{NaCl}$ with different temperature dependencies. J Neurophysiol 76:3550-3554.

Ninomiya Y (1998) Reinnervation of cross-regenerated gustatory nerve fibers into amiloride-sensitive and amiloride-insensitive taste receptor cells. Proc Natl Acad Sci USA 95:5347-5350.

Ninomiya Y, Funakoshi M (1981a) Responses of rat chorda tympani fibers to electrical stimulation of the tongue. Jpn J Physiol 31:559-570.

Ninomiya Y, Funakoshi M (1981b) Role of ions in generation of taste nerve responses to electrical tongue stimulation in rats. Jpn J Physiol 31:891-902.

Ninomiya Y, Funakoshi M (1988) Amiloride inhibition of responses of rat single chorda tympani fibers to chemical and electrical tongue stimulations. Brain Res 445:319-325.

Ninomiya Y, Funakoshi M (1989) Selective procaine inhibition of rat chorda tympani responses to electric taste stimulation. Comp Biochem Physiol 92A:185-188.

Ninomiya Y, Mizukoshi T, Higashi T, Katsukawa H, Funakoshi M (1984a) Gustatory neural responses in three different strains of mice. Brain Res 302:305-314.

Ninomiya Y, Higashi T, Katsukawa H, Mizukoshi T, Funakoshi M (1984b) Qualitative discrimination of gustatory stimuli in three different strains of mice. Brain Res 322:83-92.

Ninomiya Y, Tanimukai T, Yoshida S, Funakoshi M (1991) Gustatory neural responses in preweanling mice. Physiol Behav 49:913-918.

Oakley B (1975) Receptive fields of cat taste fibers. Chem Sens Flav 2:52-63.

Saito T, Shibamori Y, Manabe Y, Yamaguchi T, Igawa H, Yamamoto T, Ohtsubo T, Saito H (2001) Intraoperative identification of regenerated chorda tympani nerve and its relationship to recovered taste function. J Otorhinolaryngol Relat Spec 63:359-365.

Scott TR, Giza BK (1990) Coding channels in the taste system of the rat. Science 249:1585-1587.

Stevens DR, Selfert R, Bufe B, Muller F, Kremmer E, Gauss R, Meyerhof U, Kaupp B, Lindemann B (2001) Hyperpolarization-activated channels HCN1 and HCN4 mediate responses to sour stimuli. Nature 413:631-635.

St. John SJ, Smith DV (2000) Neural representation of salts in the rat solitary nucleus: brain stem correlates of taste discrimination. J Neurophysiol 84:628-638.

St. John SJ, Markisons S, Spector AC (1995) Salt discriminability is related to number of regenerated taste buds after chorda tympani nerve section in rats. Am J Physiol 269:R141-R153.

Spector AC, Guagliardo NA, St. John S (1996) Amiloride disrupts NaCl versus $\mathrm{KCl}$ discrimination performance: implications for salt taste coding in rats. J Neurosci 76:8115-8122.

Takeda M, Shishido Y, Kitao K, Suzuki Y (1981) Biogenic monoamines in developing taste buds of mouse circumvallate papillae. Arch Histol Jpn 44:485-495.

Ye Q, Heck GL, DeSimone JA (1991) The anion paradox in sodium taste reception: resolution by voltage clamp studies. Science $254: 724-726$.

Ye Q, Heck GL, DeSimone JA (1993) Voltage dependence of the rat chorda tympani response to $\mathrm{Na}^{+}$salts: implications for the functional organization of taste receptor cells. J Neurophysiol 70:167-178. 